\title{
The Language of Fear in Children's Literature: A Case Study of Ted Hughes's Poems for Children
}

\author{
Elżbieta Chrzanowska-Kluczewska \\ Uniwersytet Jagielloński \\ ORCID: 0000-0002-0908-1711
}

\begin{abstract}
The article tackles the issue of the language of fear exploited in children's literature, taking Ted Hughes's Nature poems for young readers as the object of analysis. It presents a perspective of linguistic stylistics and literary semantics and as such is not meant to be a critical literary evaluation of Hughes's poetry. Rather, it focuses on linguistic instruments of creating the aura of fear in children's poetry and their cognitive import. The author has chosen a neuroscientific paradigm for the two closely related emotions - fear and anxiety - as propagated by American researcher Joseph LeDoux, most prominently in his work Anxious (2015). LeDoux maintains that the feeling of fear is not inborn but rather a cognitive construct emergent from the use of one's native language practiced within a particular socio-cultural context. The unique atmosphere of Hughes's poetry has been achieved by a rich lexicon of fear-related notions and a skillfully applied figuration (anthropomorphisms, similes). His poetic imagery powerfully complements the vocabulary and troping in calling to life fictional worlds, often uncanny and menacing, remote from the young readers' experience. The author of this article perceives in the lexicon, figuration and multimodal imagery (both verbal and visual, the latter realized as illustrations in picture-books) an important didactic device that teaches children how to manage fearsome experiences. This capability will also prepare children to face anxiety, an emotion typical of adult life and related mostly to existential problems.
\end{abstract}

Keywords: fear, Joseph LeDoux, children's poetry, Ted Hughes, the lexicon/ figuration of fear, anthropomorphism, verbal and visual imagery, fear-management

\section{Język strachu w literaturze dziecięcej. Studium przypadku wierszy dla dzieci Teda Hughesa}

Abstrakt: Artykuł podejmuje temat języka strachu wykorzystywanego w literaturze dziecięcej na przykładzie poezji Natury adresowanej do młodego czytelnika autorstwa Teda Hughesa, brytyjskiego poety II poł. XX w. Napisany z perspektywy stylistyki językoznawczej i semantyki literackiej, artykuł nie stawia sobie za cel krytyczno-literackiej oceny poezji Hughesa, lecz skupia się na językowych środkach wywoływania atmosfery strachu w poezji adresowanej do młodego czytelnika i na ich wymiarze kognitywnym. Autorka przyjęła dla opisu dwu blisko spokrewnio- 
nych ze sobą emocji - strachu (fear) i obawy/lęku (anxiety) - model propagowany przez amerykańskiego neurobiologa Josepha LeDoux, w szczególności w jego dziele Anxious (2015). W opinii LeDoux uczucie strachu nie jest nam wrodzone, lecz powstaje jako konstrukt kognitywny wyłaniający się w procesie używania języka ojczystego w określonym kontekście społeczno-kulturowym. Szczególna atmosfera poezji Hughesa to rezultat zastosowania bogatego słownika terminów powiązanych z uczuciem strachu, jak również zręcznie powiązanej z nim figuracji (antropomorfizmy, porównania). Poetyckie obrazowanie skutecznie dopełnia leksykon i tropy, powołując do istnienia światy fikcyjne, często dziwne i groźne, odległe od doświadczenia młodego odbiorcy. Autorka postrzega leksykon, figurację i obrazowanie (zarówno werbalne, jak i wizualne poprzez ilustracje w książkach dla dzieci) jako ważny instrument dydaktyczny, uczący dzieci, jak stawić czoła przerażającym doświadczeniom. Ta umiejętność przygotowuje też młodych czytelników do zmierzenia się w przyszłości z obawą/lękiem, emocją typową dla dorosłego życia, a związaną głównie z problemami egzystencjalnymi.

Słowa kluczowe: strach, Joseph LeDoux, poezja dla dzieci, Ted Hughes, leksykon i figuracja strachu, obrazowanie werbalne i wizualne, zarządzanie strachem

“'The bigger the fright', said Uncle Mick, 'The more it can inspire us'. He filled his ceiling with the portrait of a vicious virus".

(T. Hughes, "My Uncle Mick", 2005/2008, 50)

\section{By Way of Introduction}

Wystan H. Auden's poem “The Age of Anxiety” (1947) won recognition owing to its title rather than the content itself. Joseph LeDoux, an American cognitive neuroscientist, in his influential book Anxious. The Modern Mind in the Age of Anxiety (2015, 6-7) provides a diagram illustrating the impact of this title on Anglophone popular culture, reverberating conspicuously in Leonard Bernstein's symphony of the same title (194749), a Mel Brooks film High Anxiety (1977), or - more indirectly - in a much earlier cinematic release Vertigo by Alfred Hitchcock (1958). Indeed, since the late 1940 s, constant claims that "ours" is an epoch of particular anxiety and fear have all too frequently been voiced in a whole range of discourses. The two related feelings, fear and anxiety, have remained the focus of attention of LeDoux for a considerable part of his research career. ${ }^{1}$ It is his theory of the two above-mentioned emotions that will serve as the methodological background for our short excursion into the real and imaginary universes of Ted Hughes's books for children - the poetry that teaches children how to face fearsome aspects of Nature, related mostly to death caused by a variety of reasons, not

${ }^{1}$ LeDoux has a band of his own, The Amygdaloids, who released a CD called Anxious simultaneously with his book. Earlier, in 2005, they had put out an album titled Theory of My Mind. The songs point intertextually to LeDoux's work as a neuroscientist. 
only the disease hinted at in the motto heading this article. In choosing LeDoux's scientific paradigm as a basis for our considerations, I have been motivated by his genuine concern for the role of language and specifically its vocabulary and semantics in general, in shaping human emotions right from childhood into a maturity.

The topic was raised again in the lecture delivered online by LeDoux on 6 October 2020, when he emphasized the need to watch our wording carefully while voicing theoretical claims. He also pointed out something that may come as a surprise of sorts - it is not mandatory to possess the word 'fear' in our native language in order to be able to experience and respond to a threatening situation. Yet, many languages boast a substantial lexicon related to fear and anxiety. LeDoux $(2015,9)$ claims we have thirty-odd words in English descriptive of these two basic emotions, which he calls The Lexicon of Fear and Anxiety. In turn, Saif M. Mohammad (2017), has compiled the Affect Intensity Lexicon (AIL), which contains approximately 6,000 English words associated with or connotating four basic emotions - fear, joy, sadness and anger (of which 1,765 words relate to fear itself) - and has arranged them on a scale of intensity running from o to 1 (0.1..., 0.2..., 0.3 ...etc.).

\section{Fear and Anxiety Distinguished}

In everyday parlance these two feelings or emotions are frequently taken to be similar if not of the same nature, hence the lexemes 'fear' and 'anxiety' are often used interchangeably, as synonyms or quasi-synonyms. Yet, they refer to different experiences, which should be clearly distinguished:

In fear [...] the focus is on a specific external threat, one that is present or imminent, whereas in anxiety the threat is typically less identifiable and its occurrence less predictable - it is more internal, and in the mind more of an expectation than a fact, and can also be an imagined possibility with a low likelihood of ever occurring. (LeDoux 2015, 7)

In short, we are afraid of objectively existing dangers but anxious in a much vaguer way, mostly about future events that ultimately may not happen at all. Fear, in this sense, seems to be more pristine and basic than anxiety - the latter being a more sophisticated, often prolonged state of worry about existential threats. Søren Kierkegaard (1844/1980) traced the source of anxiety to our freedom of choice and the human condition in general. Similarly, in Contributions to Philosophy (1999), Martin Heidegger mentions three dispositions, or modalities of thought, to wit: panic or horror (das Erschrecken), reservedness (die Verhaltenheit) and fear (die Scheu), which - according to Alejandro A. Vallega's $(2009,29)$ explanation - refer to existential or metaphysical experiences "of undergoing the abandonment of being in the epoch of machination." Clearly, these modalities are closer to anxiety than fear and the terminology used by Heidegger is another 
case of certain semantic laxness in using specialized terms vaguely and ambiguously. ${ }^{2}$

One well-known, if not to say popular psychological theory, developed by Paul Ekman (cf. Ekman 1992a), ${ }^{3}$ includes fear among six basic emotions, the others being anger, disgust, surprise, happiness and sadness. What's more, Ekman (1992b) related them to what he claimed to be universal facial expressions (cf. LeDoux 2015, 121-23). Ekman followed in the footsteps of Tomkins, who distinguished eight primary emotions, namely: surprise, interest, joy, rage, fear, disgust, shame and anguish (cf. LeDoux 2015, 121-22). Ekman's theory of basic emotions implied firstly that they are universally shared among humankind and, secondly, that they belong to our inborn capacities. Both these assumptions attracted criticism on the part of psychologists, neuroscientists and philosophers. LeDoux belongs to the group that has challenged the tacit or direct assumptions of Ekmanian theory. His own stance in this respect maintains that "the conscious feelings labeled with basic emotion terms are not prepackaged innate states that are unleashed by external stimuli but instead are cognitively assembled in consciousness" (LeDoux 2015, 123-24). It follows, then, that fear is a cognitive construct and that the way it is shaped by human beings is also influenced by a particular socio-cultural context. In light of such theoretical claims the role of particular vernacular languages in shaping fear and other emotions cannot be underestimated.

I find it useful to summarize at this point the updated "Survival Circuit View of Fear" proposed by LeDoux (2015, Figure 2.7, 45), which we can call for short the fear system. A threat stimulus activates the Defensive Survival Circuit in the brain, and specifically in the amygdala. The circuit establishes a Defensive Motivational State responsible for eliciting defensive actions and reactions (avoidance, freezing, flight, fight, faint, cf. Bracha 2004). However, the conscious feeling of fear requires an additional activation of cognitive systems (attention, working memory etc.). On this approach,

${ }^{2}$ Dictionary definitions appear also very general, tending to conflate the two experiences, cf. the "adult" definition of 'fear' in Merriam-Webster Online Dictionary: "an unpleasant often strong emotion caused by anticipation or awareness of danger" and kids definition therein: "a strong unpleasant feeling caused by being aware of danger or expecting something bad to happen”. Longman Dictionary of Contemporary English, New Edition $(2003,578)$ defines fear as: "the feeling you get when you are afraid or worried that something bad is going to happen." Both these descriptions could refer in equal measure to fear and anxiety. Note that the terms feeling and emotion are used in them interchangeably. So does LeDoux in his work, treating them as synonymous, although A. Damasio in Descartes' Error (1994) takes emotion to indicate an unconscious state while feeling to refer to a conscious experience. In turn, Mohammad (2017, 174) uses an umbrella term affect inclusive of emotions, feelings, and attitudes.

${ }^{3}$ The theory, with strong Darwinian roots, was propounded by Silvan Tomkins in the 1960 s, but Ekman developed and popularized it later in a number of works. He also related basic emotions to apparently equally basic facial expressions (Ekman 1992b; cf. also LeDoux 2015, 121-123). 
fear itself does not cause defense responses. The Survival Circuit operates unconsciously, triggering physiological and behavioral reactions that we share with other living creatures. Fear and anxiety, however, demand a more sophisticated conscious elaboration by our mind and psyche:

Fear/anxiety is the cognitive awareness that you are in danger, regardless of whether that danger triggers a defensive, energy regulation [...] or other survival circuit, or whether the danger is imagined, or whether it results from the contemplation of the meaning (or meaningless[ness]) of existence. (LeDoux 2015, 145)

\section{Emergence of the Feeling of Fear in Child Development. Discourses of Fear}

LeDoux's theory clearly emphasizes the role of language and acculturation in the development of the emotion of fear in children. He invokes the formation of children's emotional schemas as expounded by Jean Piaget (1971). While listening to the language of adults (mostly caretakers), reading simple texts and contemplating illustrations in picture-books, watching films and videos etc., children construe a catalogue of templates with canonical examples of different emotions. Such schemata of emotions are labelled with proper emotion words:

As one becomes more emotionally experienced, the states become more differentiated. Fright comes to be distinguished from startle, panic and terror, and dread distinguished from concern, wariness and edginess. Because the labeling process is imprecise and depends on individual learning and interpretation, each person may use the terms a little differently. (LeDoux 2015, 226)

LeDoux argues, in effect, that our feelings do not come to us as ready, inborn patterns. He refers to an article by John P. Forsyth and Georg H. Eifert (1996), who voice a similar idea: "[...] we learn what feelings are and this learning has a social-verbal experiential basis" (LeDoux 2015, 225).

The next point LeDoux is making concerns the fact that every language possesses its own semantics which is socially and culturally contextualized, hence the very fact that we can translate the fear/anxiety lexicon across various languages does not guarantee that we refer to exactly identical shades of these emotions as experienced individually. Even if our native language lacked the very nouns 'fear' and 'anxiety', our schooling in how to recognize the gamut of fear-related experiences, appearances, reactions and how to behave adequately (garnered also from our visual experience of how people affected by fear look or comport themselves) would allow us to cognitively process these emotions. LeDoux $(2015,226)$ quotes psychologist Michael Lewis (2013), who maintains that "children act afraid and anxious long before they can feel these emotions." We can thus assume that in doing so, they utilize their observations collected from various sources, children's literature being not a small part of this emotional education. 
Consequently, we may claim that the language of fear is necessary for children for at least three reasons: 1) to shape appropriate emotional mindsets that would help them to cope with more direct danger (and later in life with anxiety), 2) to tame death and diminish the fear of it, which is one of the fundamental sources of dread in human life, ${ }^{4}$ and 3 ) to prepare children for fear management - the techniques for the increase/decrease/ manipulation of fear (cf. Dillard and Anderson 2004). Not without reason does LeDoux $(2015,261)$ remind us that language is the most powerful aid to cope with fear, a useful instrument in psychotherapeutic approaches to fear/anxiety related to health problems.

In our adult life we are exposed to various discourses of fear, disseminated mostly through the mass media (news coverage, tabloids, popular science journals etc.), leading ultimately - through an excessive use of the rhetoric of fear - to the creation of the culture of fear (cf. Kitzinger and Williams 2005; Jeffries 2012). Audiences worldwide, as a result of the sensationalization of the media discourse and misrepresentation of facts, are manipulated to believe that we are faced with the most terrifying world to live in. Indeed, we are exposed to multifarious threats to our life and well-being: violence/crime/gangs, drug trafficking, terrorism, ecological catastrophes, fatal diseases and epidemics/pandemics, of which the recent global spread of COVID-19 is a case in point. The way of raising fear in all these cases instantiates a linguistically negative framing (Altheide 1997; Furedi 2007; Molek-Kozakowska 2016; Cap 2017).

Yet fear can act as an exciting and pleasure-generating emotion as well, as proved by several literary genres (myths, legends, fairy tales, ghost stories, Gothic fiction, fantasy, science-fiction), cinematographic productions (thrillers, horrors) or the fine arts (fantasy painting, cf. Chrzanowska-Kluczewska 2018, 2020). In his recent study devoted to neuroscientific aspects of literary narration, Paul B. Armstrong $(2020,160)$ points out that "The doubling of the like and the not like in as-if simulations helps to explain the oft-observed paradox that emotions such as fear and terror that would otherwise cause discomfort or pain can instead give rise to pleasure in aesthetic reenactments".

This second, paradoxically attractive, face of fear has been frequently exploited in children's literature - young readers seem to possess a capacious imagination, a love of nonsense and a willingness to feel scared by observing "the like" and "the not like" of the actual world translated into strange fictional universes. All these propensities of the child cognitive apparatus will find ample resources to draw upon in Ted Hughes's poetry for children embedded in a multimodal setting of picture-books.

${ }^{4}$ The Terror Management Theory (TMT) tackles the dread caused by the inevitability of one's death (discussed by Greenberg, Solomon and Pyszczynski 1997, quoted in Castano et al. 2011, 603). 


\section{Ted Hughes's Poems for Children - Education through Facing Fear}

\subsection{Ted Hughes - A Profile}

Ted Hughes (byname of Edward J. Hughes, 1930-1998), counted among the most outstanding English poets of the second half of the 2oth century, was Poet Laureate of the United Kingdom from 1984 until his death. Raised in rural and small town communities of West Riding, Yorkshire, where he became an enthusiast of hunting and fishing, in his adult life he cultivated a small farm in Devon and kept an old house, Lumb Bank, in Yorkshire, which all gave him a vast opportunity to observe the life of the surrounding nature. His first marriage to American poet Sylvia Plath ended in divorce, followed by Plath's suicide in 1963. They had two children, Frieda (b. 1960) and Nicholas (b. 1962), so it comes as no surprise that Hughes became involved in writing books for children, ${ }^{5}$ apart from producing collections of "adult" poetry, plays, volumes of translations and editing anthologies of renowned poets (William Shakespeare, Samuel T. Coleridge, Emily Dickinson, Sylvia Plath, Seamus Heaney). Between 1961 and 1995 he produced eighteen volumes of poetry and prose for children. His poems were targeted first at a very young audience and grew to be addressed to teenagers maturing into adulthood. All these books were illustrated by several outstanding artists (George Adamson, Leonard Baskin, R. J. Lloyd and Andrew Davidson among others, cf. Wikipedia 2020).

His is not a sentimental, sugary, light poetry for children, despite several playful effects such as puns, onomatopoeias, repetitions, interesting versification based on rhyme and rhythm, which all make his poems attractive to the ear. He was basically a Nature poet - his poetry for adults has been described as "without sentimentality, emphasizing the cunning and savagery of animal life" (Encyclopaedia Britannica 2020). An avid observer of animal life, he "captured the ferocity, vitality and splendor of the natural world" (ibid.) and in his well-known collection of poems Crow: From the Life and Songs of the Crow (1970), he "added a mythic dimension to his fascination with savagery" (ibid.). Several of these features are conspicuously present in his poetry addressed to the young, though mitigated to a certain extent at least. The creatures that people his poetic

${ }^{5}$ As rightly pointed out by one of my Reviewers, the very "fact that a poet/writer has children is not an immediate reason why he or she should turn to children's literature. Many authors turn to children's literature for the possibilities it offers". Yet, from what we know from a tumultuous biography of Hughes, his first children's poems were written for his son and daughter as a consolation after the tragic loss of their mother and might have been his personal way of coping with remorse. A genuine intentio auctoris is never fully offered to their readership and I would not dare to delve into it at this point. 
worlds come either from reality or from fictional universes such as the Moon. All these worlds can be perceived as fascinating yet at the same time ominous and merciless.

To keep our discussion of Hughes's oeuvre for children within limits, the poems to be analyzed come from Ted Hughes. Collected Poems for Children (2005/2008), with illustrations by Raymond Briggs - blackand-white drawings executed in fine and suggestive line. The importance of those pictures is immense - they perfectly reflect and strengthen the atmosphere of the poems that they accompany. Altogether, the volume includes a substantial selection of poems drawn from such volumes as The Mermaid's Purse (1993), The Cat and the Cuckoo (1987), Meet My Folks! (1961), Nessie the Mannerless Monster (1964), Moon Whales and Other Moon Poems (1976), Under the North Star (1981), What Is the Truth? (1984) and Season Songs (1976). The arrangement is not chronological but proceeds from poetry for young children to works targeted at more mature readers. Needless to say, all of them are addressed to a double audience - adults will enjoy and appreciate them (albeit in a different way) no less than the primary readership.

\subsection{Semantics of Hughes's Poetry for Children}

We will consider briefly the following components of the language of fear exemplified in Hughes's poetry: 1) the emotive lexicon, 2) figuration and 3) imagery (obtained both verbally and visually).

\subsubsection{The Emotive Lexicon}

Here, we are interested both in words that refer to fear in a direct way and the lexis that - in a subtler way - creates an association with fear and builds the atmosphere of danger. LeDoux's $(2015,9)$ Lexicon of Fear and Anxiety contains the following 32 words (listed according to the graphic prominence given to them by the Author): anxious, fear, threat, worry, defense, dread, worried, threatened, danger, panicked, frightened, trepidation, scared, jitters, chilling, alarmed, trembling, sweating, trapped, afraid, horror, fearful, timid, foreboding, nervous, restlessness, obsessive, hesitant, troubled, apprehensive, phobic, disturbed.

They are mostly nouns, adjectives and participles in the adjectival function (worried, sweating) descriptive of various degrees of fear and anxiety, as well as physical symptoms of being afraid/scared. LeDoux's Lexicon is worth comparing with a short selection of the most frequent fear-related words drawn from Mohammad's AIL, which demonstrates what kind of fears/anxieties haunt the contemporary anglophone adult: attack, catastrophe, cancer, carcinogenic, damage, dangerous, deadly, death, disability, disaster, dying, horrific, kill, pain(ful), radiation, severity, 
suicide, terrifying, terrorism, terrorist, torture, threaten, tumor, war (cf. also Gałuszka 2019:33)

Since both LeDoux's and AIL lists are mixed lexicons that cover expressions of fear and anxiety used by contemporary adults, we can presume that the lexicon utilized by Hughes a couple of decades previously will be different for socio-political reasons and with anxiety mostly dropped out of consideration in favor of the pristine feeling of fear. Here comes the lexicon of fear gathered from a selection of his poems:

Nouns: ache, anaconda, battlefield, blood, carrion, chopper, cockroach, corpse, the dead, death, famine, fear, (a shark's) fin, fright, ghost, ghosttown, graveyard, hell, hideosity, jaws, knife, limbs, monster, murderer, murk, nightmare, orphan, pain, panic, precipice, predator, scare, scream, shadows, shake, shark, shock, shriek, the sick folk, skeleton, skull, spider, stare, strangler, tears, terror(s), tiger, vampire, victim, virus, witch, wound, wraith.

Adjectives: affrighted, barbaric, bleeding, crooked/the crookedest, cruel, dark, dead, dreadful, drowned, dry, evil, fearful, ghastly, grim, haunting, hideous, horrendous, horrible, lost, numb, poisonous, scorched (soul), sinister, snakey, terrible, terrific, unhuman, vicious, wicked/the wickedest, wild.

Verbs: beat, bite, cry, devour, die, frighten (to the death), glare, grind, panic, pierce (to death), pour (into a person), roar, slay, snap (the head off), stab, sting, strike (fatally), suck (blood, the soul), tremble.

This imposing vocabulary, which will build and enrich the young readers' lexicon for life, refers to emotional and physical experiences (fright, nightmare, panic), to death and its paraphernalia including corpses and limbs separated from the body, skulls and skeletons, wounds and blood, to sounds/voices of dread and suffering, to terrifying creatures, both real and imaginary (e.g. the Moon-creatures, which are Hughes's invention), to folklore and fairy-tales, stories of witches and their abominable practices of digging up corpses and boiling them, to ghosts and vampires, to diseases and - interestingly - ugliness (cf. hideousness of the Loch Ness monster, who complains: "I am so ugly, it's just incredible", 58). ${ }^{6}$ Apart from the dominant category of nouns, the list of adjectives and verbs referring in a direct or indirect way to fear is quite rich.

Interestingly, Hughes describes several physical symptoms indicative of the state of fear: "Your stare goes dry" (9), "our hair stands up straight" (50), "quaking with fear" (60), "To see the twilight White Owl wavering over dew-mist/startles my heart" (176), "a needle slips in through your ear and

${ }^{6}$ The theme of ugliness and deformation as related to the atmosphere of dread has been exploited extensively in European visual arts (to mention only fantasy paintings of Hieronymus Bosch, Arcimboldo, Heinrich Füssli, Arnold Böcklin, or Salvadore Dali), as well as in literature. The prime instance of the latter is the corporeal monstrosity of the Frankenstein creature in Mary Shelley's famed Gothic novel (cf. Chrzanowska-Kluczewska 2020). 
brain" (an effect of hearing a hare's cry, 180). Below, I quote an excerpt from "A Moon Man-Hunt", where the real life situation has been reversed, with foxes in red jackets hunting down the gentry; the description of a squire turned game lists all the symptoms of being scared to death:

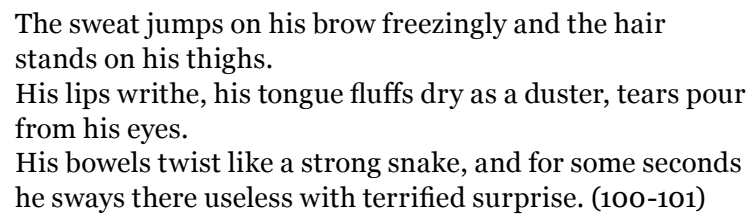

In poems dedicated to older children, fear becomes supplanted with another Ekmanian basic emotion, that of sadness. The direct vocabulary related to the description of death lurking everywhere in the animal world (the death of a young swallow with a broken wing, a young calf that soon will be butchered, a mother-lamb crying over her dead lamb) is limited to nouns such as melancholy, distress, despair and woe, otherwise the atmosphere is construed indirectly throughout entire poems.

The main source of fear meandering through the majority of Hughes's poems for children is death, associated mostly with "the great chain of food", predators and hunting, no matter whether we read about real or fictitious animals and creatures. Death through illness is not represented that frequently - the exception are the diseases on the Moon such as a moon-cloud gripe, a tree disease (when a tree starts growing inside your body), a cactus-sickness (when pimples bud on your body, "Each one into a head with hair/And a face just like the one you wear", 89-90), a disease of being filled up with moon-shadows or having your soul sucked by the crow. Interestingly, only one of them is curable (when a moon-raven swallows a disease flitting from the sick person's mouth, 93). The mysterious vicious virus from our motto is, on the other hand, a generalized threat, not directly related to any disease in particular. Nature can be sick as well, as demonstrated by the growth of moon-cabbages that are obnoxious "bundles of great loose lips" or "bundles of flapping ears" (91).

These ailments are distantly related to some legends and folk superstitions, present in European tradition, like a tree-disease, or the belief that: "In every moon-mirror lurks a danger. Look in it - and there glances out some stranger" ("Moon-Mirror", 71). Yet another tale invoked by Hughes in "Cormorant" claims that dead sailors return to earth:

\footnotetext{
Drowned fishermen come back

As famished cormorants

With bare and freezing webby toes

Instead of boots and pants. (5)
}

This sketchy outline of Hughes's "Poetic Lexicon of Fear for Children" needs to be completed by the discussion of figurative devices that are woven into the fabric of his poetic texts and an emergent imagery. 


\subsubsection{Figurative Devices}

In the functional model of figuration I have developed elsewhere (Chrzanowska-Kluczewska 2013), troping should be studied at three hierarchical levels, depending on its textual scope. Microtropes organize phrases and at most sentences, macrotropes structure longer portions of text, while megatropes tacitly underlie the entire text at the conceptual level. The application of figurative devices in children's literature would undoubtedly require a separate study; suffice it to say at this point that literal language takes precedence over figurative expressions in texts addressed to younger readers, who have not as yet developed a deeper literary competence, Figures that appear in, for instance, fairy tales and poems for the young usually include cases of comparisons and similes, some metaphors, metonymies, synecdoches and hyperboles, to the exclusion of irony or catachresis, by which term I indicate a trope of generalized semantic abuse (and which can cover figures such as oxymoron, paradox, hysteron-proteron, metalepsis etc.).

The figuration that appears in Hughes's poetry is a good case in point. At the micro-level, the dominant trope is simile, which is a fundamental figure, pointing out to children similarities in the surrounding world that are sometimes not immediately recognizable. For illustration, the eyes of a lost seal pup are "as wild/And wide and dark/As a famine child" ("Seal", 3); the witches once burned at stake on the Earth live now on the Moon, "looking exactly like cockroaches" ("Moon-Witches", 95); the same moon-witch "comes as a sort of smoke", "feels about like a spider's arm", sucking her victim empty until "[h]e collapses like a balloon ("A Moon-Witch", 98); a misfit young swift is "like a broken toy"("Swifts", 207); a thunder reverberates "As if ghosts were creaking all over the house" ("He Gets Up in Dark Dawn", 198).

The poem titled "The Warm and the Cold" features a long chain of similes (sixteen in all) that bind three long stanzas and two short ones into a coherent unity and can be considered a macrotrope that imposes a semantic structure on the entire poem. Just to give you a feeling of it:

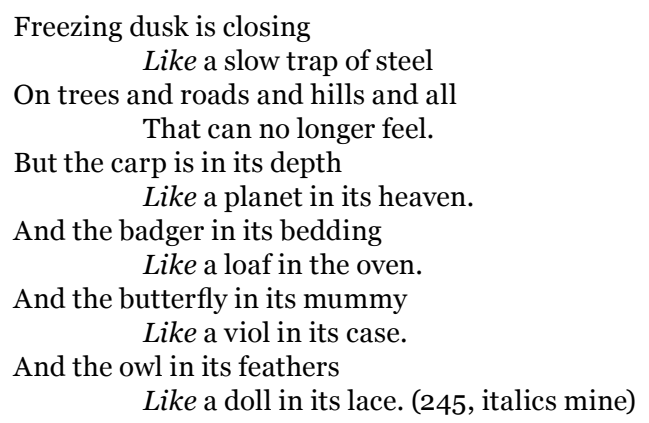

And yet, the dominant macrotrope in several of Hughes's poems is personification, or more broadly - anthropomorphization, which has always 
been a prominent feature of fables, fairy-tales and children's literature in general. Animals - the protagonists of Hughes's oeuvre - are an obvious target of anthropomorphic metaphors, with trees and plants (including grass and corn) coming next, followed by personification of inanimate objects, such as a gun "thinking" and "smiling" in the poem "Somebody" (183-85) that discloses the cruelty and nonsense of hunting for pleasure. "Somebody" impersonates a fox - "[a]n elegant gentleman, beautifully dressed", shot down by the poetic persona and his companion. When his unusually beautiful black tail "thick and long as a forearm" has been chopped off as a trophy, the rest of his body is bundled into a hole "like picnic rubbish". The poem is an intricate interplay of similes and metaphors, humanizing as well as reifying the fox. An interesting combination of these two opposing metaphors is visible in the following excerpt from "The Hare (II)": " The Hare is a very fragile thing" (reification) that "cries with human pain/And becomes a human baby on the road" (personification), when hit by a car (177). Also, the Hare, if brought home in winter storm, can turn "by firelight into a tall fine woman who many a strange tale told" ("Hare (V)", 179).

Hughes does not avoid irony completely. A peacock made show of his fan in front of the people but: "O much as we admired his plumes/A Fox admired him more" ("Peacock", 33). This ironical allusion has to be deciphered by a young reader/listener possibly with the help of an adult. It is also didactic in a subtle, indirect way. In the poem "Riddle" (151), the unnamed protagonist is again a cunning old fox, who "will conduct the orchestra" "[i]n the flea-ridden hen-house". My favorite is the ironic closure of the poem "The Mermaid's Purse", the tragic story of a mermaid who - sitting on a rock - was about to take an aspirin from her purse when a black shark appeared suddenly, introducing himself as a "Nurse and Surgeon". The poem is supported by a much-telling picture of an open purse left on the rock and the sinister fin emerging from water: "Now headache/And head have gone/Or she'd feel worse". This final commentary on the sad story of the mermaid with a migraine devoured by the cruel shark is meant to partly alleviate the sadness of a young reader by means of black humor.

In turn, the poem "There Came a Day" (234) contains an instance of animalization (theriomorphism of traditional stylistics) whereby the autumn day is presented as a predator devouring summer, with details presented rather straightforwardly: "Wrung its neck/Plucked it/And ate it".7

LeDoux $(2015,50)$ points to the fact that anthropomorphism might well be an innate capacity of the human mind, an inclination to impose human

${ }^{7}$ LeDoux, in his lecture, quoted an adage attributed to Darwin that it is kinder to think of animals in human terms than to treat human beings as animals. In consequence, animalizing metaphors appear in general less frequently than anthropomorphisms. Apart from the instance of animalizing autumn, Hughes exploits this metaphor also in the description of the hunting of well-born people by revengeful foxes in "The Moon Man-Hunt" (cf. 3.2.1.). 
(and humane) behaviors and feelings onto Nature in general, referring to previous research in this area (Kennedy 1992; Mitchell, Thompson and Miles 1996; Decety 2002). Anthropomorphization denotes first and foremost a mapping of human features and characteristics onto animals but also onto inanimate objects, even geometrical figures. LeDoux (2015, 50) quotes an instance of a video film in which a large triangle chases and bumps into a small circle that tries to avoid this contact by changing course. The watching subjects were prone to personify the figures, ascribing to them the characteristics of being an "aggressive" attacker and a "fearful" victim, respectively. An excellent illustration of this kind of metaphor is the macropersonification that structures Hughes's poem "Moon-Horrors" (77-78) by depicting hideous and vicious numbers - number nines, "oneeyed, one-legged", strike their victims fatally, number sevens suck them in, number threes come as nightmares turning the sleeper "inside out", and the silent zero is shown as a flying strangler. All of them are repulsive and terrifying, mainly due to the fact they have been animized, if not straightforwardly personified. In this capacity, anthropomorphic metaphors achieve functionally the widest scope in Hughes's poems as megafigures that present the real world and the alternative universes as peopled with living creatures of every possible sort.

Apart from frequent similes and all-pervasive animizing metaphors that sometimes overlap with irony, Hughes's poems also contain some cases of synecdoche (pars pro toto, here mostly of the body-part kind), both verbal and visual. The latter shows in Briggs's excellent illustrations, like a menacing black fin standing for the shark the mermaid-eater (10), or "the Sun's red eye/which seems to fry/In the dawn sky" and which frightens a simple pig, the more so that it resembles a "dreadful" fried egg ("Pig", 22), or the carrion-bird crow drumming "into an old thigh-bone" thus reminding us that a bone may be all that ultimately remains of a human body ("Horrible Song", 35-6).

An ingenuously applied micro-, macro- and megafiguration, rich enough but not overwhelming for a young reader to cope with, together with a substantial fear lexicon, build the often uncanny atmosphere of Hughes's poetry. The third building block is a powerful imagery, to be discussed next.

\subsubsection{Verbal and Visual Imagery}

The worlds that Hughes calls to life in his poetry are rich in inhabitants of all sorts - from a wide range of farm animals and poultry that will be close to children's experience (sheep, cows and calves, horses and foals, pigs, cats, dogs, goats, donkeys, rats, hens and geese, to mention some of them), all kinds of wild birds (with prominence granted to swallows, crows and rooks, owls and predatory birds), wild animals that people 
forests and meadows (foxes, wolves, bears, badgers, hares etc.), northern animals (snowy owls, eagles, seals, lynxes, wolverines, moose, musk-oxen etc.), and sea-creatures (seals, gulls, cormorants, crabs, octopi, anemones, fish, sharks, whales etc.) to human beings ("my folks") that only superficially resemble the child's closest family but in fact belong to alternative realities, looking and behaving in weird ways, the imaginary creatures that inhabit the Moon or the actual world, some of them legendary, often ominous and cruel personages (witches, ghosts, shadows, wraiths - like a horrifying Wendigo that takes revenge on trappers for all the animals they have killed). The last sort are scary, often ugly and vicious creatures, the most fear-inducing in Hughes's collection of impossible individuals. One of them, the Loch Ness monster, Nessie, is only superficially scary due to its mere bulk but turns out to be a lonely creature whom the British Queen soon befriends. The fact that legendary and imagined creatures are denizens of distant text worlds, to use the term borrowed from possible-worlds semantics, makes them a challenge but also a trigger to set the child's imagination in motion.

Since the collection that we discuss is a picture-book, understandably, illustrations together with the text will construe the atmosphere of the poems. These exquisite and unobtrusive drawings fulfil the basic educational aim of presenting a given animal or creature to the child. In many cases they are full of charm, raising sympathy for and understanding of the non-human life. Some of them, however, depict frightened animals such as a young seal (3), a boy crouching on the shore, terrified by the sudden appearance of Nessie, presented synecdochically only as a huge neck emerging from water (9), another young boy on a beach listening to a shell ("The sea fills my ear/With sand and with fear", 11), or a boy in the position called freezing according to fear theories (Bracha 2004) at the sight of a dragonfly approaching him ("Snakey stripes, a snakey fright! / Does he sting? Does he bite?", 25). Another picture (93) features a sick boy, lying still, the moment an illness flits like a moth out of his mouth, to be instantly swallowed by a silvery-white moon-raven, the bird that looks scary but turns out to be one of few benevolent inhabitants of Hughes's Moon.

While educating children how to face, cope with and, ultimately, tame fear, omnipresent in the actual and imaginary worlds, the so-called fear-management techniques are applied. Fear-increase may utilize the visual modality to strengthen the overall effect, as in the cases described above. The opposite strategy, fear-decrease, is masterfully deployed by Hughes in the poem "The Moon-Hyena" (85-6). The first three stanzas present this scary monster synecdochically, through its most salient characteristics - an uncanny laughter, tumbling and rolling over the Moon's surface. "A laughter of dark hell, /Mad laughter of a skull" predicts an appearance of a huge animal "[c]oming to devour the living ones". Suddenly - to our surprise - stanza four dispels the horror: 


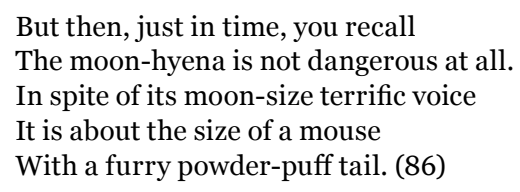

The moral of this story is that - frequently - the things or individuals that apparently pose a threat to us turn out not to be dangerous at all. In this way the child is taught to examine frightening objects, animals and personages with caution but in a reasoned way. After all, fear manipulation (Dillard and Anderson 2004) is what children and teenagers will soon be exposed to in their adult life through fear-propagating language present especially in the discourses disseminated through the mass (including social) media.

\section{Conclusions}

In his lecture LeDoux quoted Ralph Waldo Emerson's apothegm: "As soon as there is life, there is danger". Accordingly, LeDoux claims that life is all about not being dead and that danger-avoiding behavior is as old as life itself, present even in unicellular protozoa that have no nervous system. The situation with sophisticated feelings/emotions is completely different: "Hunger, like anger, fear, and so forth, is a phenomenon that can be known only through introspection" (Nico Tinbergen quoted in LeDoux's lecture). The feeling of fear requires the construal by a developed brain, able to perform complex cognitive operations, supported by the embeddedness in a specific social and cultural environment/context and largely shaped by our native language.

I personally think that our age is no more vulnerable and consequently prone to anxiety than other periods of human history. Mankind has been constantly affected by wars and plagues, while our planet has been ravaged by climate changes and natural disasters. It is true that the 2oth century - the epoch of barbarous large-scale homicides and devastating wars, the age of spreading criminal gangs and of the birth of global terrorism - duly deserves the title of "The Age of Anxiety". The 21st century has challenged us with a pandemic that has already affected millions, badly shaken the global economy and is still threatening the majority of the Earth's population; it has also impacted our personal liberties. We do not know what other terrors may be lurking in the future, but as highly adaptive intelligent creatures we also realize that we have to prepare our children and the youth to be capable of standing face-to-face with fear.

After all, children have always been educated through stories that tackled the themes of danger and death. Legends and fairy-tales are very often emotionally disturbing narrations that disclose the cruelty and severity of 
life. "Little Red Riding-Hood" in Charles Perrault's original version (Perrault 2004, 66-9) has no happy-ending - both the grandmother and the heroine are simply devoured by Wicked Woolf. The tale is appended with a warning moral that disappeared in later "mollified" versions. Strangely enough, we owe the tale's more happy closure to the Brothers Grimm, with the culprit Wolf trapped and killed, although The Grimms' tales in general abound in gruesome incidents.

Hughes's poetry, despite being described as unsentimental, is not entirely devoid of meeker feelings. Several of his children's poems show a great fondness, tenderness and sympathy towards animals, which also live in a constant dread of losing their life and their young. Death-related topics reflect the characteristics of Nature and the excursions into the poetic worlds of the impossibilia, even if fearsome, broaden the child's horizons and open up distant vistas, no longer homely and safe, yet intriguing and worthy of exploration (cf. Chrzanowska-Kluczewska 2007 on unfriendly possible worlds of our imagination and fiction). ${ }^{8}$

Undoubtedly, the role of language seems crucial in developing human emotional life. ${ }^{9}$ It not only describes threats and frightful experiences but is instrumental in overcoming fear and anxiety via introspection, in a verbal examination and evaluation of our experiences and, ultimately, in fear-management. Psychiatric treatment conducted with the aid of language (conversations, explanations, advising) in many cases brings better effects than medical treatment of fear/anxiety, targeted at the symptoms but not at the cognitive sources of these emotions (cf. LeDoux 2015, Ch. 9-11 on psychotherapy and medical treatment of anxiety). ${ }^{10}$

The neurological perspective developed by Le Doux with respect to fear and language restitutes - in my opinion - the importance of literature in children's upbringing. Most certainly, not the entire children's literature has to be based on fear-inducing lexicon, troping and imagery. At the end opposite to Hughes's "tough" poetic oeuvre we come across educational concrete poetry for primary school children authored by the American poet Joan Bransfield Graham, titled Splish Splash (1994) and Flicker Flash

${ }^{8}$ Piotr Cap (2017) proposed the Proximization Theory (PT) in his discussion of the language of fear used in public discourses. Things and matters distant from our experience are potentially more fear-inducing. The same phenomenon was discussed extensively within the text-world theories of fiction, and fantasy in particular. John R. R. Tolkien called the universes of fairy-tales and of his own fiction The Perilous Realm (cf. Chrzanowska-Kluczewska 1994, 204). The fearsome, terrifying aspect of such remote worlds can make them unfriendly to unprepared readers (Chrzanowska-Kluczewska 2007).

${ }^{9}$ LeDoux $(2015,155)$ also emphasizes - quite rightly - the role of language in metacognition and the importance of syntax in structuring mental processes, enabling us to plan future actions and evaluate their possibility.

${ }^{10}$ In Lamaism (Tibetan Buddhism), The Tibetan Book of the Dead (Bardo Thrötröl) is a prominent instance of coping with death- and incarnation-related experiences by means of language. It has been traditionally read as an instructional text to the dying or immediately following their demise (Chrzanowska-Kluczewska 2018). 
(1999), teaching them about natural phenomena related to the occurrence of water and light under many guises. This poetry, in a light mood, shows the beauty and pleasure of the surrounding world, with no elements related to danger and fear.

The function of visuals in multimodal texts such as picture-books is no less important - no matter whether these are monochrome drawings by Raymond Briggs or joyful illustrations by Steve Scott (Splish Splash) and Nancy Davis (Flicker Flash) that play on the color-gamut associated with water and light, respectively. Like the verbal texts that they complement, these illustrations, deploying the grammar of visual design (Kress and van Leeuven 1996/2006), help young readers to recognize emotions in other people and develop them in themselves. Fear-related phenomena are a part-and-parcel of the general education of the young and should be administered with care and diligence, but not totally avoided. ${ }^{11}$ The more exercised in coping with fear our children are, the better prepared to face anxiety in their adult life they will be.

\section{References}

Altheide, David L. 1997. "The News Media, the Problem Frame, and the Production of Fear." Sociological Quarterly 40 (3): 475-503.

Armstrong, Paul B. 2020. Stories and the Brain. The Neuroscience of Narrative. Baltimore: Johns Hopkins University Press.

Auden, Wystan H. 1947. The Age of Anxiety: A Baroque Eclogue. New York: Random House.

Bracha, H. Stefan. 2004. "Frieze, Flight, Fight, Fright, Faint: Adaptionist Perspectives on the Acute Stress Response Spectrum." CNS Spectrum 9 (9): 679-85. doi:10. 1017/ s1092852900001954.

Cap, Piotr. 2017. The Language of Fear: Communicating Threat in Public Discourse. London: Palgrave Macmillan.

Castano, Emanuele, Bernhard Leidner, Alain Bonacossa, John Nikkah, Rachel Perrulli, Bettina Spencer, and Nicholas Humphrey. 2011. "Ideology, Fear of Death and Death Anxiety.” Political Psychology 32 (4): 601-21.

Chrzanowska-Kluczewska, Elżbieta. 1994. "Proximate and Remote Possible Worlds in Literary Fiction and Their Inhabitants." In Literature and Language in the Cultural Context. Proceedings of the Inaugural Conference of Polish Association for the Study of English, Cracow-Przegorzaty, 27-30 April 1992, edited by Krystyna Stamirowska, Zygmunt Mazur, and Anna Walczuk, 195-207. Kraków: Universitas.

Chrzanowska-Kluczewska, Elżbieta. 2007. "On Interplanetary Travels Between Friendly and Unfriendly Worlds." In Cognition in Language. Volume in Honour of Professor

${ }^{11}$ In the Nepali tradition of selecting a young (four to five-year-old) girl to become a living goddess Kumari, an incarnation of Taleju, that will occupy her seat in Kathmandu's Kumari Bahal until her puberty, a major trial to which candidate girls are exposed is a test of their ability not to lose courage in a scary situation. The candidates will spend a lonely night in a dark temple of Taleju, where the freshly cut off bloody heads of sacrificial buffaloes are stored. The atmosphere of dread is heightened by terrifying noises and the appearance of figures in dreadful masks. A genuine Kumari, immune to threats by demons, should bear the trial calmly. Another important proof of being a Kumari is bodily perfection. 
Elżbieta Tabakowska, edited by Władysław Chłopicki, Andrzej Pawelec, and Agnieszka Pokojska, 555-73. Kraków: Tertium.

Chrzanowska-Kluczewska, Elżbieta. 2013. Much More than Metaphor. Master Tropes of Artistic Language and Imagination. Frankfurt am Main: Peter Lang Edition.

Chrzanowska-Kluczewska, Elżbieta. 2018. "The Taming of Death in Western and Eastern Tradition as Reflected in Texts of Culture (Arts, Sacred Texts and Crafts). Christianity vs. Tibetan Buddhism." In Disease, Death, Decay in Literatures and Cultures, edited by Ryszard W. Wolny and Katarzyna Molek-Kozakowska, 173-89. Opole: Uniwersytet Opolski.

Chrzanowska-Kluczewska, Elżbieta. 2020. "The Aesthetics of Frankenstein. Nightmarish Landscapes in European Romantic and Symbolic Fantasy Literature and Fantastic Painting." In Frankenstein 1818.2018 - Parabel der Moderne / Parable of the Modern Age. Symposium 2018 in Ingolstadt, edited by Dieter Petzold and Klaudia Seibel, 73-90. Berlin: Peter Lang.

Damasio, Antonio. 1994. Descartes' Error: Emotion, Reason, and the Human Brain. New York: Gosset / Putnam.

Decety, Jean. 2002. “[Naturalizing Empathy].” L'Encephale 28: 9-20.

Dillard, James P., and Jason W. Anderson. 2004. "The Role of Fear in Persuasion." Psychology \& Marketing 21 (11): 909-26.

Ekman, Paul. 1992a. "An Argument for Basic Emotions." Cognition and Emotion 6: 169-200.

Ekman, Paul. 1992b. "Facial Expressions of Emotions. New Findings, New Questions." Psychological Science 3: 34-8.

Encyclopaedia Britannica. 2020. “Ted Hughes.” Accessed October 10 and December 21, 2020. https://www.britannica.com/biography/Ted-Hughes.

Forsyth, John P., and Georg H. Eifert. 1996. "The Language of Feeling and the Feeling of Anxiety: Contributions of the Behaviorisms Toward Understanding The Function-Altering Effects of Language." Psychological Record 46: 1-28.

Furedi, Frank. 2007. "The Only Thing We Have to Fear Is the 'Culture of Fear' Itself." Accessed October 10 and December 21, 2020. https://www.researchgate.net/publication/238082918_The_only_thing_we_have_to_fear_is_the_culture_of_fear_itself... reprinted from: http://www.spiked-online.com/index.php?/site/article/3053/

Graham, Joan Bransfield. 1994. Splish Splash, illustrated by Steve Scott. New York: Houghton Mifflin.

Graham, Joan Bransfield. 1999. Flicker Flash, illustrated by Nancy Davis. New York: Houghton Mifflin.

Gałuszka, Katarzyna. 2019. "The Discourse of Fear in the Mass Media: A Comparison of Articles from Liberal and Conservative British and American Online Newspapers (20172018).” MA thesis, Jagiellonian University in Kraków.

Heidegger, Martin. 1999. Contributions to Philosophy (From Enowning), translated by Parvis Emad Emad and Kenneth Maly. Bloomington, Indianapolis: Indiana University Press.

Hughes, Ted. 2005/2008. Collected Poems for Children, illustrated by Raymond Briggs. London: Faber and Faber.

Jeffries, Fiona. 2012. “Mediating Fear.” Global Media and Communication 9 (1): 37-52.

Kennedy, John S. 1992. The New Anthropomorphism. Cambridge, UK; New York: Cambridge University Press.

Kierkegaard, Søren. 1844/1980. The Concept of Anxiety. A Simple Psychologically Orienting Deliberation on the Dogmatic Issue of Hereditary Sin. Princeton, NJ: Princeton University Press.

Kitzinger, Jenny and Clare Williams. 2005. "Forecasting Science Futures: Legitimising Hope and Calming Fears in the Embryo Stem Cell Debate." Social Science and Medicine 61: 731-740.

Kress, Gunther and Theo van Leeuwen. 1996/2006. Reading Images. The Grammar of Visual Design. London, New York: Routledge. 
LeDoux, Joseph. 2015. Anxious. The Modern Mind in the Age of Anxiety. London: Oneworld Publications.

LeDoux, Joseph. 2020. "As Soon As There Is Life, There Is Danger." Virtual lecture delivered in Copernicus Festival - Kraków, Poland, October 6, 2020. Accessed December 21, 2020. https://joseph-ledoux.com/pages/lecture_video_p1.html.

Lewis, Michael. 2013. The Rise of Consciousness and the Development of Emotional Life. New York: Guilford Press.

Longman Dictionary of Contemporary English. New Edition. 2003. Harlow, Essex: Pearson Education.

Merriam-Webster Online Dictionary. n.d. “Fear.” Accessed September 29 and December 21, 2020. https://www.merriam-webster.com/dictionary/fear.

Mitchell, Robert W., Nicholas S. Thompson, and H. Lyn Miles (eds.). 1996. Anthropomorphism, Anecdotes, and Animals. New York: SUNY Press.

Mohammad, Saif M. 2017. “Word Affect Intensities.” Accessed September 29 and December 21, 2020. https://www.aclweb.org/anthology/L18-1027.pdf.

Molek-Kozakowska, Katarzyna. 2016. "Framing Disease, Ageing and Death in Popular Science Journalism." Brno Studies in English 42 (1): 49-69.

Perrault, Charles. 2004. Perrault's Fairy Tales. Complete and Unabridged, translated by Amelia E. Johnson. Ware, Hertfordshire: Wordsworth Editions.

Piaget, Jean. 1971. Biology and Knowledge. Edinburgh: Edinburgh University Press.

Vallega, Alejandro A. 2009. Sense and Finitude. Encounters at the Limits of Language, Art, and the Political. Albany, NY: State University of New York Press.

Wikipedia. 2020. "Ted Hughes." Accessed October 10 and December 21, 2020. https:// en.wikipedia.org/wiki/Ted_Hughes\#Books_for_children. 